\section{Recognizing gift-horses}

A European complaint against Japanese chipmanufacturers is misguided.

What is the right price for a piece of silicon whose surface has been configured as memory in a computer of some kind? Manufacturers of these devices know well enough that there is no simple answer. Chip-making is the archetypal capital-intensive business. The raw material is a material looking like a metal extracted from one of the most common materials on the surface of the Earth. Because computer memory chips are unavoidably small in size, there are few ways in which their manufacture can be guided by human hands, which are orders of magnitude larger. But the machinery required to manufacture chips is unavoidably expensive. The capital cost of a chip-making plant can easily be several times the annual salary bill of all the people it employs. The result is that the price at which a manufacturer can afford to sell his products must be very much like the answer to the question about the length of a piece of string.

This point appears not to have been appreciated in the United States by the government officials who, two years ago, negotiated the agreement between the United States and Japan on microelectronic products, which has now become a headache for the European Community as well as the United States. The agreement, much resented at the time in Europe as a kind of cartelization of international trade in microelectronics, required that Japan should not export chips to the United States at prices considered to be "too low", and that Japan should not divert cheap supplies to third markets, European countries for example. One of the consequences seems to have been that Japanese manufacturers have reduced substantially the volume of their exports of memory chips, the simplest chips, presumably because they have concluded that more complicated designs will offer a more secure market. One consequence is that computer manufacturers have been seriously inconvenienced. Another is that manufacturers and their backers in the United States and Europe are screwing up their courage to re-enter a business from which they retreated nearly a decade ago in the face of competition from Japan.

Meanwhile, nobody seems much the wiser about the proper price for a simple memory chip. In reality, in such a capitalintensive business, the price can legitimately vary within an enormous range. When demand is high and supply short, the price can be what the market will bear - usually much greater than the manufacturer needs to cover the cost of amortizing the plant that he has built. At the other extreme, when chips are abundant, the economic price need not be much greater than the cost of the purified silicon each contains. Strictly speaking, simply to break even requires that a manufacturer should collect enough revenue from the chips he sells to pay his workforce and to amortize his capital investment, which makes the economic price of a single chip a sensitive function of the volume of sales. Given the Japanese talent for making complicated machinery function efficiently, is it any wonder that Japanese manufacturers have been able to undercut their competitors elsewhere?

This is one reason why it is difficult to tell what to make of the formal complaint the European Commission is being asked to make against Japanese chip manufacturers, which may be accompanied by some form of financial sanction. Another is that the complaint apparently refers to the period 18 months ago, before Japanese manufacturers turned their attention to more complicated kinds of chips. Now, European manufacturers of computer hardware, are howling at having to pay nearly $\$ 10$ a chip for the supplies on which they can lay their hands. The moral is that people who believe that others are selling products at prices which are "too low" by their own standards should usually rejoice - provided that the trick is not accomplished by government subsidy or by breaking in some other way the rules of the General Agreement on Tariffs and Trade.

\section{Who pays the piper...}

The public interest should not come second to the need for publication.

Roughly a decade has passed since the first enthusiasms about the prospect of curing inherited defects of metabolism and other functions by the transplantation of normal genes - and many more decades may pass if the enthusiasts behave as Dr W. French Anderson is reported (on page 577) to have done last week in providing evidence for the US National Institutes of Health's Recombinant DNA Committee (RAC).

Anderson and his colleagues, who are well-known for their careful studies over many years of the candidate gene transplants with which to begin, now wish to make a gene transplantation in human subjects designed to test the viability of transplanted foreign genes rather than to rid people of a condition they have inherited. Anderson may share the opinion of many others that the RAC is making heavy weather of the issue, or may alternatively believe that, on a matter with such beneficent potential, it is more prudent that the first essays in an unavoidable direction should be cautious, with crosses on every "t" and dots on every "i". Whatever the truth, it seems to be a fact that the RAC subcommittee charged with oversight of gene transplantations believed it needed more information about Anderson's plans, postponed a decision after receiving what it considered to be inadequate information - and was then outflanked when Anderson provided the missing information orally, at the full meeting of the RAC at which the postponement would ordinarily have been confirmed.

While such a turn of events may be regarded as a sign that even very large bureaucracies are able to respond to ordinary mortals' intervention, it also betokens a measure of afterthought in circumstances in which forethought should be at a premium. But the reasons given by Anderson for his approach to the RAC committee are especially dubious: he had not provided all the information for which the subcommittee had asked for fear that it would then be published in the general press, thus prejudicing the chances that a formal account of his work would afterwards appear in some reputable scientific journal.

This is a very odd posture, the implications of which would have startled Anderson and his colleagues if they had considered them. Biomedical research, generously supported by taxpayers in the United States, is for ridding people of disease. Gene therapy is an especially promising but untried technique of which the same taxpayers happen to be distrustful. So research in the field is supported financially while would-be practitioners are required to pass through the eyes of several needles. The understanding is that the regulations will wither away when it has been shown that gene transplantation is as safe as most people expect, and effective as well.

So what will the same taxpayers make of the assertion that navigating all those needles' eyes might have prejudiced the chance of formal publication? Not much, it seems reasonable to guess. If gene therapy is for anything at all, it is for ridding patients of disease. To the taxpayers concerned, the circumstances of eventual publication are probably irrelevant. Even professional colleagues, themselves bound up in the convention that publication is a professional necessity, may share much of that view. But to offer fears that later publication will be prejudiced by full compliance with the requirements of oversight committees must damage both the prospect that research that has become contentious will be hampered and the institutions of the scientific literature, which will be accused of putting their own interests before those of the intended beneficiaries of biomedical research. The truth is that there is no responsible journal that would put its interests ahead of the public interest, as the editors of Science and the New England Journal of Medicine have unsurprisingly confirmed. If others should behave differently, the taxpayers would ask "So what?". 